\title{
Realization of the text category of modality in Germanic languages (as exemplified in German and English stories)
}

\author{
Irina Belyaeva ${ }^{1,{ }^{*}}$, Irina Bondarenko $^{1}$, Irina Elistratova $^{1}$, Maria Zakarova $^{1}$ \\ ${ }^{1}$ Moscow Region State University, 10A, Radio str., 105005, Moscow, Russia
}

\begin{abstract}
In this article the authors studied how the TEXT CATEGORY OF MODALITY can be expressed by grammatical and lexical language features possessed by Germanic branch of Indo-European language family. As a subject of study we chose two primary languages in this group English and German - functioning in short stories. Through the method of segmental text analysis as well as statistical method conducted on English and German short stories it has been discovered that despite some frequency characteristics' differences in the text category of modality in English and German, both languages, however, have estimately the same number of features for the formation of modal architectonics in the literary text which is explained by the fact that both languages used for the study belong to the same language group. This article confirms the authors' theory about common and invariant characteristics of the text modality expressed in the stories being formed under the influence of the text's genre types - specifically having two narrative systems: author's plan and characters' plan. Specific aspects of the modality pictures discovered during this study are shown in the summary tables.
\end{abstract}

\section{Introduction}

The subject of the research in this article is the category of text level modality.

The object of research - language content of the designated category in the texts of short stories in English and German.

The main purpose of this article is to establish general, specific and invariant features of modal organization of texts of short stories in German and English.

The increasing interest of linguists in the category of modality is due to the fact that this text category allows evaluating a statement in the context as true or false, as real or unreal, as possible or necessary. According to the genre peculiarities of the text and its style, different approaches to defining the concept of modality are distinguished.

What is the meaning of the term "modality"?

By the term "modality" Agaeva F.A. understands the functional and semantic category as a system of heterogeneous language features (morphological, lexical, lexicalsyntactical), capable of interacting when expressing the correlation of the statement's content to reality from the the speaker's perspective [1, p. 11]. Among the linguists engaged

* Corresponding author: taniasemina@gmail.com 
in the analysis of texts, gained recognition the concept put forward by I.R. Halperin, who noted the particular difficulty of determining the category of modality in the literary text because the text modality "is dispersed in a mass of estimates of individual elements of the text, and the phrase modality to some extent replaces the text's one" [3]. Thus, text modality is expressed by the relative segments of the text.

E.A. Goncharova sees in the literary text two relatively independent segments: one that is of an author's and that of a character. "Both in author's and character's segment there is possible an introspective way of portraying a character: through description of his inner state in author's speech and in literary forms of characters' inner speech transmission" [4]. Thus, in works of fiction it is possible to distinguish the author's speech plan and the character's speech plan, which, in turn, convey the character and author's modality.

"The presence in the story narrative of the author's and characters' segments suggests considering the composition of the story as a single system consisting of two modal subsystems: author's and characters'. Each of the above subsystems has its own expression plan, therefore further it is possible to name these subsystems accordingly - the modal speech plan of the author (MSPA) and the modal speech plan of characters (MSPC)" [6].

It is commonly assumed that the basic grammatical means of expression of modality is an inclination. The category of mood is considered to be one of the most important verb categories. There are three types of mood:

Table 1. Types of mood.

\begin{tabular}{|c|c|c|c|}
\hline German & Indikativ & Konjunktiv & Imperativ \\
\hline English & Indicative & Subjunctive & Imperative \\
\hline
\end{tabular}

Linguists E.V. Gulyga and E.I. Shendels divide the modal macrofield into the field of certainty, which is given more space in speech, and the field of uncertainty, which is divided into three microfields: the potentially unreal microfield, the imperative microfield and the supposition microfield [5].

In English, the issue regarding the number of mood types remains unresolved. Traditionally, in English grammar there are three types of mood: indicative, imperative, subjunctive [8], and the category of modality is represented by the category of mood as well as modal verbs, modal equivalents and modal expressions.

\section{Study materials and methods}

The research material consisted of 45 texts of literary prose (short stories) in German and English. We consider a short story a small prose genre of epic prose with its inherent deep psychologisms subtext of the events with a small volume of the plot; for a story by virtue of its composition are typical modal speech plan of the author and modal speech plan of characters [6].

The method of segment analysis of texts establishes the specification of text structure by the category of modality and determines its language content.

The algorithm for analyzing the category modality in this paper includes the following steps:

1. Form of narration (first person; third person)

2. Correlation of author's speech to character's speech (mono-systemic/poly-systemic text)

3. Presence/absence of a single modal key in the text (monomodal/multimodal text).

4. Identification of language means forming the modality category (homogeneity/inhomogeneity) 
5. Modality determination of the text (presence or absence of language features that form the text category under study)

6. Grammatical features for expressing modality (forms of mood, imperative forms of verbs, etc.)

7. Lexical features of modality expression (modal verbs, modal words, interjections, emotionally intensive words and particles, etc.)

This research methodology takes into account the main approaches to the category of modality:

1. as a lexical-grammatical category, when the methods of expression by grammatical and lexical means are taken into account.

2. as a semantic category expressed in a language by various language features of the functional-semantic field with the category of mood at its core.

Besides, in this study we used the statistical method of direct calculation of the number of use of modal verbs, modal equivalents and expressions to reveal prevailing modality models in texts of English stories.

As an example of the application of the above methodology for analyzing the text category of modality we will give an example of segment analysis of the story by a German writer Heinrich Böll "Just Like in Bad Novels" [16].

According to the step-by-step algorithm of the applied methodology, first of all, anthropocentric characteristics of the text in question should be determined. First of all, it is necessary to determine the form of narrative. In this story is used first person narrative, that is, the main character is the narrator. However, in the text we can see the use of both singular (personal pronoun "ich", including all grammatical forms of its case paradigm) and plural forms of the first person (personal pronoun "wir", including all grammatical forms of its case paradigm) equally, which is associated with the referent composition of the story, in particular: the main figures - a married couple, the protagonist and his wife Berta. This is the interesting moment from the linguistic point of view, when of the main text corpus there is mostly an covert adhesion of the author's plan with that of a character, namely, with the plan of the main character. Nevertheless, the story undoubtedly presents two systems: the author's system and the character's system.

Methods of expression of modal structure of the literary text as a whole, regardless of its genre, significantly differ in the author's speech and in the speech of characters [7, p. 15]. The main component of the modal text structure is the category of mood. In the author's speech the indicative mood is strongly intertwined with the subjunctive mood, this way diluting the author's narrative of the events expressed in Indikativ by adding structures with the meaning of assumption, advice, recommendation or regret, expressed by the means of Konjunktiv II.

For example:

Wenig später stellte ich mich hinter das Badezimmerfenster und dachte darüber nach, warum Zumpen die Einladung wohl angenommen hatte; er konnte nicht viel Interesse daran haben, mit uns zu Abend zu essen, und die Tatsache, dass morgen bestimmt werden sollte, wer die große Arbeit übernehmen würde, zu der ich mich auch bereit erklärt hatte, hätte ihm die Sache genauso unangenehm machen müssen, wie sie es für mich war.

In this example, in addition to the Konjunktiv II of the modal verb sollen and Konjunktiv II Plusquamperfekt of the modal verb müssen, a special form of the German subjunctive is used - the Konditionalis I of the verb übernehmen.

Along with Konjunktiv II, Konjunktiv I also appears in the author's speech to convey the words of the heroine Bertha in the form of indirect speech. For example:

Als wir die Treppe hinuntergingen, sagte Bertha, dass sie glücklich sei, aber ich schwieg. 
The speech of the characters is also characterized by a variety of grammatical forms of the category of mood used here:

„Und wenn es Mitternacht wäre“, sagte Bertha, ,, soviel ich weiß, gilt es 20000 Mark. Glaub nicht, dass die so empfindlich sind. "

This example illustrates the combination of three forms of mood in characters' plan: subjunctive (Konjunktiv II), indicative and imperative (Imperativ second person singular).

The use of Konjunktiv II Plusquamperfekt as well as Konditionalis I in characters' plan should also be emphasized:

„Bitte“, sagte sie sanft, ,,du hättest ihn aus irgendeinem Grunde in dein Arbeitszimmer bitten und dort mit ihm sprechen müssen. Du hast doch bemerkt, wie sehr er sich für Kunst interessiert. Du hättest sagen sollen: Ich habe da noch ein Brustkreuz aus dem 18. Jahrhundert, vielleicht würde es Sie interessieren, das zu sehen, und dann... “

It should be noted that Imperative Mood which was not presented in the author's speech, in terms of frequency of use in characters' speech is not inferior to the Indicative and Subjunctive Mood. The protagonists of the work use all forms of the Imperative, with the exception of the second person plural:

„Langsam“, flüsterte Bertha, ,, warte, bis sie geklingelt haben, lass sie zwei oder drei Sekunden stehen, dann geh langsam zur Tür und öfne. “

The above example shows the form of the second person singular Imperative, with the verbs forming a model of an imperative chain in the text.

The next fragment represents the form of politeness:

„Und nun“, sagte Frau Zumpen, „,nur noch eine Kleinigkeit. Nehmen Sie Ihr Scheckbuch und schreiben Sie einen Scheck über dreitausend Mark aus. “

Besides the listed forms of the Imperative Mood in the characters' plan also found the form of the first person plural:

„Also “, sagte Frau Zumpen lächelnd, „,trinken wir! “

Thus, based on the examples presented, we can argue that the forms of the Imperativ Mood in the characters' speech of the German short story play an important role in the formation of modal architectonics of the text, which is not true for the author's speech, where the use of Imperativ is absent.

The results of the modal expression analysis of Heinrich Böll's story "Just Like in Bad Novels" are presented in Table 2 below.

Table 2. Modal image of the German short story "Just Like in Bad Novels" by H. Böll.

\begin{tabular}{|l|c|c|c|c|c|}
\hline & Indikativ & Konjunktiv & Imperativ & Modal verbs & $\begin{array}{c}\text { Modal } \\
\text { words }\end{array}$ \\
\hline $\begin{array}{l}\text { Author's } \\
\text { plan }\end{array}$ & + & + & - & + & + \\
\hline $\begin{array}{l}\text { Characters' } \\
\text { plan }\end{array}$ & + & + & + & + & + \\
\hline
\end{tabular}

MSPA Indikativ (Präteritum, Plusquamperfekt, Präteritum Passiv, Futur I

Zustandspassiv)

Konjunktiv I (Präsens)

Konjunktiv II (Konditionalis I,Präteritum, Plusquamperfekt )

Modal verbs (können, sollen, müssen, wollen)

Modal words (wohl, bestimmt, überhaupt)

MSPC Indikativ (Präsens, Präteritum, Perfekt, Passiv Präsens, Plusquamperfekt)

Imperativ

Konjunktiv II (Präteritum, Konditionalis I, Plusquamperfekt)

Modal verbs (können, müssen, sollen, mögen)

Modal words (natürlich, überhaupt) 
"When we consider a text as a mono-modal or multimodal unit, first of all, we refer to the presence of the following modal features: Indikativ and Konjunktiv forms of mood. The text of a fictional work usually appears to be multimodal. It is explained by the presence of two modal plans: author's and characters', each of them being expressed by various modal language features" [6].

The analysis of a short story "If Sharks Were People" by Bertolt Brecht shows the possibility of realization of an author's concept by means of Subjunctive Mood with rare addition of Indicativ. This short story is written in third person singular narrative. There are two referents in the story: Mr. K. and his companion, the young daughter of the landlady who's house he rented. We observe the conversation between two people from the sidelines. However, it can be argued that this is rather Mr. K's monologue, his reflections on the topic "If sharks were people...", in which the assumption which is present in each sentence intertwines with the unreality, impossibility of the desired, which is expressed by forms Konjunktiv I, Konjunktiv II, modal verbs and modal words.

The author's plan of the narrative, which opens the story, is represented by two verbs in Inticativ (fragte die kleine Tochter, sagte er).

„Wenn die Haifische Menschen wären“, fragte Herrn K. die kleine Tochter seiner Wirtin, ,, wären sie dann netter zu den kleinen Fischen?" „Sicher“, sagte er.

Next comes the answer-monologue of Mr. K. himself, presenting the characters' speech plan with a variety of explicit modal tools:

„Wenn die Haifische Menschen wären, würden sie im Meer für die kleinen Fische gewaltige Kästen bauen lassen, mit allerhand Nahrung drin, sowohl Pflanzen als auch Tierzeug. Sie würden dafür sorgen, dass die Kästen immer frisches Wasser hätten, und sie würden überhaupt allerhand sanitärische Maßnahmen treffen, wenn z.B. ein Fischlein sich die Flosse verletzten würde, dann würde ihm sogleich ein Verband gemacht, damit es den Haifischen nicht wegstürbe vor der Zeit.

Damit die Fischlein nicht trübsinnig würden, gäbe es ab und zu große Wasserfeste; denn lustige Fischlein schmecken besser als trübsinnige.

Es gäbe natürlich auch Schulen in den großen Kästen. In diesen Schulen würden die Fischlein lernen, wie man in den Rachen der Haifische schwimmt. Sie würden z.B. Geographie brauchen, damit sie die großen Haifische, die faul irgendwo rumliegen, finden könnten. Die Hauptsache wäre natürlich die moralische Ausbildung der Fischlein. Sie würden unterrichtet werden, dass es das Größte und Schönste sei, wenn ein Fischlein sich freiwillig aufopfert, und sie alle an die Haifische glauben müssten, vor allem, wenn sie sagten, sie würden für eine schöne Zukunft sorgen. Man würde den Fischlein beibringen, dass diese Zukunft nur gesichert sei, wenn sie Gehorsam lernten. Vor allen niedrigen, materialistischen, egoistischen und marxistischen Neigungen müssten sich die Fischlein hüten, und es sofort melden, wenn eines von ihnen solche Neigungen verriete.

Wenn die Haifische Menschen wären, würden sie natürlich auch untereinander Kriege führen, um fremde Fischkästen und fremde Fischlein zu erobern. Die Kriege würden sie von ihren eigenen Fischlein führen lassen. Sie würden die Fischlein lehren, dass zwischen ihnen und den Fischlein der anderen Haifische ein riesiger Unterschied bestehe. Die Fischlein, würden sie verkünden, sich bekanntlich stumm, aber sie schweigen in ganz verschiedenen Sprachen und könnten einander daher unmöglich verstehen. Jedem Fischlein, das im Krieg ein paar andere Fischlein, feindliche, in anderer Sprache schweigende Fischlein, tötete, würde sie Orden aus Seetang anheften und den Titel Held verleihe.

Wenn die Haifische Menschen wären, gäbe es bei ihnen natürlich auch eine Kunst. Es gäbe schöne Bilder, auf denen die Zähne der Haifische in prächtigen Farben, ihre Rachen als reine Lustgärten, in denen es sich prächtig tummeln lässt, dargestellt wären. 
Die Theater auf dem Meeresgrund würden zeigen, wie heldenmütige Fischlein begeistert in die Haifischrachen schwimmen, und die Musik wäre so schön, dass die Fischlein unter ihren Klängen, die Kapelle voran, träumerisch, und in der allerangenehmste Gedanken eingelullt, in die Haifischrachen strömten.

Auch eine Religion gäbe es ja, wenn die Haifische Menschen wären. Sie würde lehren, dass die Fischlein erst im Bauche der Haifische richtig zu leben begännen.

Übrigens würde es auch aufhören, dass alle Fischlein, wie es jetzt ist, gleich sind. Einige von ihnen würden Ämter bekommen und über die anderen gesetzt werden. Die ein wenig größeren dürften sogar die kleineren fressen. Dies wäre für die Haifische nur angenehm, da sie dann selber öfter größere Brocken zu fressen bekämen. Und die größeren, Posten innehabenden Fischlein würden für die Ordnung unter denn Fischlein sorgen, Lehrer, Offiziere, Ingenieure im Kastenbau werden.

Kurz, es gäbe erst eine Kultur im Meer, wenn die Haifische Menschen wären "[23].

Due to the fact that the characters' plan is implemented by Subjunctive Mood (Konjunktiv form), and Indicative forms do not affect the author's intention, we consider the story to be monomodal texts. The modal core of the whole work is an irreal modality.

The modal layout of B. Brecht's story is reflected in Table 3 below.

Table 3. Modal image of the German short story «If Sharks Were People» by B. Brecht.

\begin{tabular}{|l|c|c|c|c|c|}
\hline & Indikativ & Konjunktiv & Imperativ & Modal verbs & $\begin{array}{c}\text { Modal } \\
\text { words }\end{array}$ \\
\hline $\begin{array}{l}\text { Author's } \\
\text { plan }\end{array}$ & + & - & - & - & - \\
\hline $\begin{array}{l}\text { Characters' } \\
\text { plan }\end{array}$ & + & + & - & + & + \\
\hline
\end{tabular}

MSPA Indikativ (Präteritum)

MSPC Konjunktiv I (Präsens, Zustandspassiv Präsens)

Konjunktiv II (Präteritum, Präteritum Passiv, Konditionalis I Passiv,

Konditionalis I, Zustandspassiv Präteritum)

Indikativ (Präsens, Präteritum, Zustandspassiv Präsens)

Modal verbs (können, müssen, dürfen)

Modal words (sicher, natürlich, unmöglich, überhaupt, übrigens)

The modal speech plan of the author and characters is not represented by the forms of Imperative Mood. The characters use two forms of the category of mood Indikativ and Konjunktiv. However, we can see a rich palette of grammatical, lexical and syntactical elements involved in the formation of modal architectonics of B. Brecht's story "If Sharks Were People".

The story "Esmé" by an early 20th century English writer H. H. Munro (Saki) was chosen as an example of English text analysis. First of all, we would like to focus on the main characteristics of the story. These are the main heroine's memories of a hunting incident. The events are presented as a dialogue between the storyteller, the Baroness, her acquaintance Clovis and the Baroness' acquaintance Constance, who took part in the story's events. The story is almost entirely written in Indicative Mood, given that an actual real life events are being recalled. The narrative has many examples of the use of various modal means to express the narrators' feelings about the events described. These are various forms of modal verbs, modal expressions and their equivalents:

"It's a hyaena", I cried; “it must have escaped from Lord Pabham's Park" [19] — where the modal verb must with the Perfect Infinitive expresses the speaker's absolute certainty of the events happened earlier.

"What are we to do?" "What a person you are for questions", I said. "Well, we can't stay here all night with a hyaena," she retorted. "I don't know what your ideas of comfort 
are, "I said; "but I shouldn't think of staying here all night even without a hyaena. My home may be an unhappy one, but at least it has cold and hot water laid on, and domestic service, and other conveniences which we shouldn't find here. We had better make for that ridge of trees to the right; I imagine the Crowley road is just beyond" [19]. - The situation is tense. Hunters came across a hyena instead of a fox and do not know what to do, using in their speeches various modal verbs and expressions corresponding to their psychological state. The rhetorical question with to be to, the use of "emotional" should, modal verbs may in the meaning of the assumption with a lesser degree of certainty, and can with the meaning of the possibility that depends on the circumstances and, finally, the modal expression indicating the desired action had better do smth. The above language tools are used in this context to emphasize the absurd situation as well as the emotional imbalance of the protagonists.

"Merciful Heaven!" screamed Constance, "what on earth shall we do? What are we to do?" [19] — The modal verb shall in first person plural emphasizes the contextual meaning of the heroine's uncertainty about her further actions by semantic repetition of the meaning by a subsequent question with the modal verb to be to.

"Personally I was doing everything that occurred to me at the moment...I really don't know what I could have done". [19] - is the only example of the use of Subjunctive Mood in the story. The Subjunctive Mood is expressed by the past tense of the modal verb "can" in combination with Perfect Infinitive. Thus, the form "could + Perfect Infinitive" expresses an action that could not have occurred in the past.

"You have killed my Esme," I exclaimed bitterly. "I'm so awfully sorry," said the young man; I keep dogs myself so I know what you must feel about it. I'll do anything I can in reparation"... "I'm afraid he must have been rather a valuable animal"...Constance snorted loudly. "Don't cry, dear", I said brokenly; "It was all over in a moment. He couln't have suffered much". [19] — the modal verb must in this context shows both the meaning of duty, responsibility in combination with Indefinite Infinitive and the unquestioned confidence of the speaker in their words; the modal verb can with Indefinite Infinitive indicates real physical ability, while the form "could + Perfect Infinitive" - the speaker's uncertainty regarding the incident.

"I'm perfectly certain that at the Last Jugement Constance will ask more questions than any of the examing seraphs" [19] — the modal expression to be perfectly certain as well as the modal verb will in the third person singular in combination with Indefinite Infinitive express the confidence of the speaker in the reality of future actions. Moreover, in this context, will obtains sarcastic connotation.

"In the first place, I can't prevent it," I said; "and in the second place, whatever else he may be, I doubt if he's ravening at the present moment". [19] — In this example, physical inability to perform the action is expressed by the modal verb can in a negative form while the uncertain assumption - by a verb with the modal meaning of doubt and the modal verb may.

Table 4 shows the modal layout of the short story "Esmé" by H. H. Munro (Saki).

Table 4. Modal image of the English short story "Esmé" by H. H. Munro (Saki).

\begin{tabular}{|l|c|c|c|c|c|}
\hline & Indicative & Subjunctive & Imperative & Modal verbs & $\begin{array}{c}\text { Modal } \\
\text { words }\end{array}$ \\
\hline Author's plan & + & - & - & - & - \\
\hline $\begin{array}{l}\text { Characters' } \\
\text { plan }\end{array}$ & + & + & + & + & + \\
\hline
\end{tabular}

MSPA The Indicative Mood (Past Indefinite)

MSPC The Indicative Mood (Present Indefinite, Present Continuous, Present Perfect, Past Indefinite, Past Continuous, Past Perfect) 
The Conditional Mood (could + Perfect Infinitive)

The Imperative Mood (Present Indefinite)

Modal verbs (to be to, shall, will, must, can)

Modal words (I suppose, to be going to, evidently, to be sure, probably, had better do smth, perhaps).

The author's Modal Speech Plan (MSPA) is represented by only a few sentences in Past Indefinite, while the characters' modal speech plan (MSPC) is represented by different forms of the category of mood as well as variety of modal verbs and words. In the story, modal features contribute to understanding the author's intention by pointing out different shades from emotional tension and doubt to certainty.

\section{Study Results}

As a result of the conducted research it is possible to draw a conclusion that the defining genre indicator for the category of modality in the short story as a type of text is the identification of two systems: the author's plan and the plan of characters. Depending on belonging of a text material to one of the specified systems it is possible to reveal the basic features of language content of a text structure of a modal category. The key feature in this case was a quantitative factor identified through the use of quantitative research method. Conducted on the material of English and German stories, this method helped to establish the frequency differences in the use of linguistic (grammatical and lexical) features in order to express the text category of modality.

\section{Discussion of the Results}

This study found that the modality category is common for all analyzed texts with the short story text type, regardless of which of the two Germanic languages (English or German) chosen for the study they were written in. However, if the text grid of the author's plan category of modality is less polynomial than the linguistic content of the category of modality in the characters' plan, then according to quantitative criterion, namely the semantics of the expressed intentions, modal speech plan of the author is identical to the modal speech plan of the characters. Modal expressions and modal equivalents in both systems can consider action as possible, probable, impossible or obligatory.

\section{Conclusion}

On the basis of the results of the conducted research it is possible to draw an important linguistic and textologists conclusion that the Germanic languages represented in the work, more precisely English and German, despite having certain differences in their language systems, mostly show similarities in the formation of modal architectonics of texts of English and German stories. The genre indicator of a story defining nature of key text modality and language content of the text grid of this category, is existence and parallel functioning of two systems: the author's plan and the plan of characters.

Therefore, the research has confirmed the theory that the variation of language features in the construction of a text category of modality in literary texts in languages belonging to the Germanic branch of the Indo-European family of languages is determined primarily by the genre features of a certain type of text. Systemic differences in languages, however, are secondary. 


\section{References}

1. F.A. Agaeva, Modal'nost' kak lingvisticheskaya kategoriya: Avtoref. dis. na soisk. uchyon. step. dokt. filol. Nauk (Baku, 1990)

2. I.F. Belyaeva, Voenno-gumanitarnyj al'manah, ser. Lingvistika YAzyk. Kommunikaciya. Perevod. Materialy X Mezhdunarodnoj nauchnoj konferencii po aktual'nym problemam teorii yazyka i kommunikacii 1 iyulya (M.: Izdatel'skij dom «Mezhdunarodnye otnosheniya», 2016)

3. I.R. Gal'perin, Tekst kak ob"ekt lingvisticheskogo issledovaniya (M., Nauka,1981)

4. E.A. Goncharova, Lingvisticheskie sredstva sozdaniya obraza personazha $v$ hudozhestvennom tekste. Lingvisticheskie issledovaniya hudozhestvennogo teksta (L., 1983)

5. E.V. Gulyga, E.I. SHendel's, Grammatiko-leksicheskie polya v sovremennom nemeckom yazyke (M., 1969)

6. I.V. Elistratova, Harakter vzaimodejstviya kategorii informativnosti $i$ kategorii modal'nosti $v$ tekste hudozhestvennogo proizvedeniya (zhanr rasskaza): dis. ... kand. filol. Nauk (M., 2001)

7. M.Y. Zaharova, ZHanrovo-grammaticheskie osobennosti nemeckoj dramy. Avtoref. dis. na soisk. uchyon. step. kand. filol. nauk (M., MGOU, 2009)

8. I.P. Ivanova, V.V. Burlakova, G.G. Pochepcov, Teoreticheskaya grammatika sovremennogo anglijskogo yazyka: Uchebnik (M., Vysshaya shkola, 1981)

9. M.N. Levchenko, Interpretaciya teksta i ego grammaticheskih modelej (tipologicheskij aspekt) monografiya (M., Izd-vo MGOU, 2013)

10. M.N. Levchenko, Modal'nost'v sovremennom nemeckom yazyke. Ucheb. posobie dlya samostoyatel'noj raboty studentov lingvisticheskogo fakul'teta (M., MPU, «Signal"», 2000)

11. O.I. Moskal'skaya, Tekst - dva ponimaniya $i$ dva podhoda. Russkij yazyk, funkcionirovanie grammaticheskih kategorij. Tekst $i$ kontekst (Vinogradovskie chteniya) (M., 1984)

12. L. Nozdrina, A Interpretaciya hudozhestvennogo teksta. Poetika grammaticheskih kategorij (M., 2009)

13. Nozdrina L A 2004 Poetika grammaticheskih kategorij: Kurs lekcij po interpretacii hudozhestvennogo teksta (M., TEZAURUS, )

14. L.N. Poluyanova, Lingvostilisticheskie osobennosti teksta basni (na materiale angloyazychnoj literaturnoj basni): Avtoref. diss. ... kand. filol. Nauk (M., 2001)

15. E.V. Ushakova, Social'no-gumanitarnyj vestnik YUga Rossii. Centr social'nopoliticheskih issledovanij «Prem'er» 7-1, 135 (2010)

16. H. Böll, Erzählungen (Dänemark, Egmont, Aschehoug A/S, 1973)

17. E. Brinker, Linguistische Textanalyse (Berlin, Erich Schmidt, 1988)

18. H.-D. Gelfert, Wie interpretiert man eine Novelle und eine Kurzgeschichte? (Stuttgart, Reclam, 1993)

19. Munro Hector Hugh, The Collected Short Stories of Saki (Ware, Wordsworth Editions Limited, 1993)

20. G. Holtz-Baumert, Alfons Zitterbacke: Ucheb. posobie na nem. Yaz (M., Izdatel'stvo «Menedzher», 2004)

21. W. Jung, Grammatik der deutschen Sprache (Leipzig, 1996) 
22. O.J. Moskalskaja, Grammatik der deutschen Gegenwartssprache. 2. Aufl (M., 1975)

23. http://www.graf-gutfreund.at/daf/02grammatik/01verb/05konjunktiv/ue_konjunktiv_ brecht_haifische.pdf 